\title{
The ability of immobilized bacterial consortia and strains from river biofilms to degrade the carbamate pesticide methomyl
}

\author{
C. S. Chen $\cdot$ T.-W. Wu $\cdot$ H.-L. Wang $\cdot$ \\ S.-H. Wu $\cdot$ C.-J. Tien
}

Received: 1 March 2014/Revised: 11 July 2014/Accepted: 21 September 2014/Published online: 30 September 2014

(C) Islamic Azad University (IAU) 2014

\begin{abstract}
Complex microbial communities from river biofilms might contain microorganisms capable of degrading xenobiotic pollutants such as pesticides (e.g. methomyl, which is commonly detected in rivers). Therefore, this study was used to determine the methomyl degradation potential of bacteria consortia and single bacterial strains acclimatized and isolated from natural river biofilms to provide biomaterials for bioremediation of water that is contaminated with methomyl. Natural river biofilms were culture enriched with methomyl as the sole carbon source to obtain acclimatized bacterial consortia and single bacterial strains. The microbial consortium on the ceramic discs was able to remove $91 \%$ of added methomyl $\left(50 \mathrm{mg}^{-1}\right)$ in 7 days. The longer-acclimatized bacterial consortium on loofah sponges removed methomyl more quickly than the shorter-acclimatized consortium, but both had similar removal capabilities (i.e. 92.4 and $92.2 \%$ ). This finding suggested that the former might contain more methomyl degraders than the latter. However, after preservation at 25,4 and $-20^{\circ} \mathrm{C}$ for 1 or 3 months, the methomyl degradation ability of the bacterial consortia decreased significantly, indicating loss of methomyl degraders during preservation. Three bacterial species were
\end{abstract}

C. S. Chen · T.-W. Wu · H.-L. Wang · C.-J. Tien $(\varangle)$

Department of Biotechnology, National Kaohsiung Normal University, 62 Shen-Chung Road, Yanchao, Kaohsiung 824, Taiwan

e-mail: cjtien@nknu.edu.tw

S.-H. Wu

Department of Safety, Health and Environmental Engineering, National United University,

Miaoli, Taiwan isolated from acclimatized river biofilms, and only one species, identified as Sphingomonas sp., was able to remove methomyl, with a 7-day removal rate of $44.7 \%$ when sugar was added and of $32.5 \%$ when no sugar was added. These results suggested that an additional carbon source might slightly improve the ability of Sphingomonas sp. to degrade methomyl. Acclimatized bacterial consortia have a higher potential for treating methomyl-contaminated water than isolated bacterial species.

Keywords Bacteria - Degradation - Methomyl . Preservation $\cdot$ River biofilm

\section{Introduction}

River biofilms are composed of diverse heterotrophs and autotrophs that are highly efficient at removing inorganic and organic compounds from river water. Sorption of large amounts of nickel by natural river biofilms was observed by Hitchcock et al. (2009). Sorption and metabolism of aniline, atrazine, diclofop methyl, diazinon, carbofuran, carbaryl and methomyl by river biofilm communities has also been found (Lawrence et al. 2001; Araya et al. 2003; Tien et al. 2011, 2013). Thus, river biofilms might contain microorganisms with the ability to degrade organic contaminants such as pesticides.

Methomyl belongs to the carbamate pesticide family, and it has been extensively used for foliar treatment of vegetable, fruit, field crops, cotton, and commercial ornamental plants as an insecticide or ovicide (USEPA 1998). It works by inhibiting cholinesterase, an essential enzyme for proper functioning of the nervous system. Methomyl is considered very toxic for mammals (the oral $\mathrm{LD}_{50}$ was $17-24 \mathrm{mg} \mathrm{kg}^{-1}$ in male rats and $15 \mathrm{mg} \mathrm{kg}^{-1}$ in guinea 
pigs), and it is classified by USEPA as Toxicity Category I. It is also toxic for aquatic organisms, with a $3.4 \mathrm{mg} \mathrm{l}^{-1}$ methomyl 96-h $\mathrm{LC}_{50}$ in rainbow trout and an 8.8-31.7 $\mu \mathrm{g}$ $\mathrm{1}^{-1}$ 48-h LC $\mathrm{LC}_{50}$ in Daphnia magna (USEPA 1998).

There were three formulations of methomyl registered in Taiwan. Only $40 \%$ water-soluble granules and $24 \%$ soluble concentrate formulations are allowed to be used; the $90 \%$ soluble formulation is forbidden. Because of its high water solubility $\left(58 \%, 25{ }^{\circ} \mathrm{C}\right)$, low soil organic carbon partition coefficient $\left(K_{\mathrm{oc}}=19-34\right)$ and stability to hydrolysis (pH 5 and 7), methomyl has the potential to contaminate groundwater and surface water. Peak methomyl concentrations in water bodies near agriculture fields have ranged from 2 to $175 \mathrm{ppb}$ (USEPA 1998). Degradation of methomyl includes abiotic (hydrolysis and photodegradation) and biotic (microbial activity) processes. The degradation of methomyl by direct photolysis and environmental hydrolysis (under neutral and mild-acidic conditions) represents a minor degradation pathway in the natural environment (van Scoy et al. 2013). However, photocatalytic treatment of methomyl by photo-Fenton and $\mathrm{TiO}_{2}$, using solar energy at the pilot plant, is an efficient degradation pathway for methomyl (Malato et al. 2002). Microbial digestion of methomyl by soil microbes and activated sludge was also found to be an effective means for degradation (Farré et al. 2002; van Scoy et al. 2013). Xu et al. (2009) found that methomyl could be completely transformed to S-methyl- $N$-hydroxythioacetamidate after $10 \mathrm{~h}$ of incubation with the Paracoccus sp. mdw-1 isolated from activated sludge. Therefore, isolation of microorganisms capable of degrading methomyl could provide biomaterials for bioremediation of methomyl-contaminated water.

The objectives of this study were to determine the methomyl degradation potential of acclimatized bacterial consortia and isolated bacteria from natural river biofilms collected from Tsen-Wen River and to analyze the effects of preservation on the degradation ability of acclimatized bacterial consortia. Natural river biofilms and acclimatized bacterial consortia contained complicated bacterial community structures which cannot be characterized by conventional culture methods. Denaturing gradient gel electrophoresis (DGGE) is able to separate bacterial DNA fragments that have the same length but contain different base pair sequences in a gradient of denaturants (urea and formamide) (Muyzer et al. 1993). Bacterial diversity is then visualized from the banding pattern of the DGGE gel. Thus, this technique has been successfully used to determine bacterial diversity in river biofilms and biofilm reactor systems (Rowan et al. 2003; Lyautey et al. 2005; Tien et al. 2013). Therefore, this study employed the
DGGE technique to reveal the dynamic changes in the bacterial community structure of river biofilms during an enrichment culture and a degradation test.

\section{Materials and methods}

\section{Acclimatizing natural river biofilms}

Natural river biofilms were grown on unglazed ceramic discs $(4.5 \mathrm{~cm}$ diameter and $0.7 \mathrm{~cm}$ thickness) for the enrichment culture and degradation tests. The reasons to use unglazed ceramic discs for colonization of river biofilms were not only to obtain a fixed surface area for the tests, but also to have the bacterial community structure similar to those formed on natural stones in river beds (Araya et al. 2003). Fifty ceramic discs were hung on a paint-covered steel rack with plastic strings and submerged in river water to a $1 \mathrm{~m}$ depth, parallel to the current flow, for 21 days under the Se-Kung Bridge $\left(23^{\circ} 6^{\prime} 26^{\prime \prime} \mathrm{N}\right.$, $120^{\circ} 12^{\prime} 18^{\prime \prime} \mathrm{E}$ ) of the Tsen-Wen River, which has intensive agriculture activity nearby. It was expected that river biofilms grown at this site might contain bacteria capable of degrading methomyl.

After 21 days, the ceramic discs were fully covered with river biofilms, and they were brought back to the lab. There, the natural river biofilms on the 20 ceramic discs were subjected to continuous enrichment culture for 28 days in a 2-1 beaker that contained 1-1 mineral salt medium (MSM) enriched with $50 \mathrm{mg}^{-1}$ methomyl as the sole source of carbon; the cultures were incubated at $25{ }^{\circ} \mathrm{C}$ without illumination. The components of MSM per litre of distilled water are as follows: $\left(\mathrm{NH}_{4}\right)_{2} \mathrm{SO}_{4}, 1 \mathrm{~g}$; $\mathrm{K}_{2} \mathrm{HPO}_{4}, \quad 1 \mathrm{~g} ; \quad \mathrm{Na}_{2} \mathrm{HPO}_{4}, \quad 2.1 \mathrm{~g} ; \quad \mathrm{MgSO}_{4}, \quad 0.01 \mathrm{~g}$; $\mathrm{CaCl}_{2} \cdot 2 \mathrm{H}_{2} \mathrm{O}, \quad 0.1 \mathrm{~g} ; \quad \mathrm{FeSO}_{4} \cdot 7 \mathrm{H}_{2} \mathrm{O}, 0.001 \mathrm{~g} ; \mathrm{CuSO}_{4}$, $0.04 \mathrm{~g}$; and $\mathrm{Na}_{2} \mathrm{MoO}_{4}, 0.002 \mathrm{~g}(\mathrm{pH}=7.4)$. To provide enough methomyl to serve as the sole carbon source for bacteria within the river biofilms, fresh MSM containing $50 \mathrm{mg} \mathrm{l^{-1 }}$ methomyl was continuously fed into the beaker at the rate of $20 \mathrm{ml} \mathrm{h}^{-1}$, and the same amount of old medium was withdrawn. The medium was continuously stirred by a stir bar $(120 \mathrm{rpm})$ using a stirrer (Corning PC-410D, MA) to maintain a sufficient oxygen level. This enrichment culture system was run in replicates. River biofilms on two replicated ceramic discs in each system were collected weekly; they were scraped into phosphate buffer solution ( $\mathrm{pH}$ 7.4, Sigma, St. Louis, MO) and then were stored at $-20{ }^{\circ} \mathrm{C}$ for later determination of the bacterial diversity during the enrichment culture using DGGE. 
Determination of bacterial diversity within river biofilms

DNA of the frozen river biofilm samples was extracted using a PowerSoil ${ }^{\mathrm{TM}}$ DNA Isolation Kit (MO BIO Laboratories, Inc., Carlsbad, $\mathrm{CA}$ ) according to the manufacturer's instructions. The purity and concentration of genomic DNA were determined at $\mathrm{OD}_{260} \mathrm{~nm}$ and $\mathrm{OD}_{280}$ $\mathrm{nm}$ using a UV/Vis spectrophotometer (BioPhotometer plus, Eppendorf, Hamburg, Germany).

To increase the sensitivity and specificity of the DGGE, a nested PCR technique was used to amplify the 16S rDNA $(11 \mathrm{~F} / 1512 \mathrm{R}$ and $968 \mathrm{~F}-\mathrm{gc} / 1392 \mathrm{R})$. The pair of universal bacterial primers $11 \mathrm{~F} / 1512 \mathrm{R}$ is capable of amplifying nearly full-length (1,502 bp) $16 \mathrm{~S}$ ribosomal DNA (rDNA) from many bacterial genera (Weisburg et al. 1991). The primer set $968 \mathrm{~F}-\mathrm{gc} / 1392 \mathrm{R}$ targets highly conserved V6-V8 regions of the bacterial $16 \mathrm{~S}$ rDNA gene (439 bp) and recovers an informative and long fragment with the large overall separation distance between species by DGGE (Chang et al. 2000; Ferris et al. 1996; Heuer et al. 1997). The PCR mixture contained $25 \mu$ of $2 \times$ PCR Master Mix (1.25 $\mu$ Super Therm DNA polymerase mix, $200 \mu \mathrm{M}$ dNTPs, $1.5 \mathrm{mM} \mathrm{MgCl} 2,1 \times$ buffer, US Patents owned by Hoffman-La Roche Inc., Nutley, NJ), $1.25 \mu \mathrm{l}(0.25 \mu \mathrm{M})$ of each primer, $2 \mu \mathrm{l}$ (approximately $500 \mathrm{ng}$ ) of DNA template and $20.5 \mu \mathrm{l}$ double deionized water. The first PCR round with the primers of $11 \mathrm{~F}$ and $1512 \mathrm{R}$ was run for 30 cycles under the following conditions: after $3 \mathrm{~min}$ of initial denaturation at $95{ }^{\circ} \mathrm{C}$, each cycle consisted of denaturation at $95{ }^{\circ} \mathrm{C}$ for $90 \mathrm{~s}$, primer annealing at $52{ }^{\circ} \mathrm{C}$ for $45 \mathrm{~s}$ and primer extension at $72{ }^{\circ} \mathrm{C}$ for $2 \mathrm{~min}$, followed by a 2-min final extension step at $72{ }^{\circ} \mathrm{C}$ in the last cycle. The second PCR round with the primers of $968 \mathrm{~F}$-gc and $1392 \mathrm{R}$ was run with a hot start at $95{ }^{\circ} \mathrm{C}$ for $4 \mathrm{~min}$, followed by 35 cycles consisting of $95{ }^{\circ} \mathrm{C}$ for $45 \mathrm{~s}$ (denaturing), $58{ }^{\circ} \mathrm{C}$ for $45 \mathrm{~s}$ (annealing) and $72{ }^{\circ} \mathrm{C}$ for $45 \mathrm{~s}$ (extension), and a final extension step $\left(72{ }^{\circ} \mathrm{C}\right.$ for $10 \mathrm{~min}$ ). All PCR products were visualized by electrophoresis in $2 \%$ agarose gels after ethidium bromide staining with a Tris-acetate-EDTA (TAE) buffer system (amresco $\left.{ }^{\circledR}, \mathrm{OH}\right)$.

After the second round, PCR products were purified and concentrated by the Clean/Gel Extraction Kit (BioKit, Barcelona, Spain), according to the manufacturer's instructions. One thousand ng of purified PCR products were loaded onto a $6 \%$ polyacrylamide gel with a denaturant gradient ranging from 35 to $65 \%$. The gel electrophoresis was run for $6.5 \mathrm{~h}$ at $60{ }^{\circ} \mathrm{C}$ and $150 \mathrm{~V}$ using the DCode $^{\mathrm{TM}}$ Universal Mutation Detection System (Bio-Rad, Hercules, CA). After electrophoresis, the gel was stained with SYBR Green I nucleic acid gel stain (Invitrogen, Life
Technologies CO., Ltd., Grand Island, NY) and photographed on an Image Capture System (ImageQuant TL, GE). DGGE banding patterns were analyzed by Quantity One ${ }^{\circledR}$ software (Version 4.6.2, Bio-Rad, Hercules, CA). Clustering analysis using Dice's similarity coefficient (Crump et al. 2003) in Quantity One ${ }^{\circledR}$ software was used for computing similarity of samples. The dendrograms of sample similarity using unweighted pair group mean analysis were then produced.

Degradation test for acclimated river biofilms on ceramic discs

After the 28-day enrichment culture, the acclimatized river biofilms on 11 ceramic discs were put into a 1-1 beaker containing $800 \mathrm{ml} \mathrm{MSM}$ with $50 \mathrm{mg} \mathrm{l}^{-1}$ methomyl as the experimental group. The control group beaker contained $800 \mathrm{ml} \mathrm{MSM} \mathrm{with} 50 \mathrm{mg} \mathrm{l}^{-1}$ methomyl, without any biofilms. Both groups were incubated at $25^{\circ} \mathrm{C}$, and the medium was continuously stirred by a stir bar (120 rpm) using a stirrer (Corning PC-410D, MA) to maintain a sufficient oxygen level. After $0,1,2,3,5$ and 7 days, $50 \mathrm{ml}$ of medium (in two replicates) was collected to determine the concentrations of methomyl.

Processing and preservation of acclimatized bacterial consortia on loofah sponges

It has been found that an immobilized consortium was more convenient and advantageous for degradation of pesticides than free-living cells (Pattanasupong et al. 2004a). While ceramic discs were originally used to support acclimatized river biofilms, they may be broken during preservation and they require a large space for storage. Thus, we removed acclimatized river biofilms from ceramic discs and let them grow and attach onto loofah sponges (Pattanasupong et al. 2004b). The 28-day acclimatized river biofilms on 8 ceramic discs were removed into $300 \mathrm{ml} \mathrm{MSM}$ with $50 \mathrm{mg} \mathrm{l}^{-1}$ methomyl, using mild sonication for $2 \mathrm{~min}$. This cell suspension was put into a 1-1 beaker containing $600 \mathrm{ml} \mathrm{MSM}$ with $50 \mathrm{mg} \mathrm{l}^{-1}$ methomyl and 105 loofah sponges $(2 \mathrm{~cm} \times 2 \mathrm{~cm} \times 2 \mathrm{~cm}, 0.1 \mathrm{~g}$ sponge $^{-1}$ ). The sponges were cultured for 14 days using the continuous enrichment culture method. This allowed time for the acclimatized bacterial consortium to grow and attach onto the loofah sponges. This microbial consortium was called Bacterial consortium A. A similar microbial consortium, Bacterial consortium B, was obtained from river biofilms after both the 28-day enrichment culture and the 7-day degradation test, using the same loofah sponge procedure as for Bacterial consortium A. The purpose for 
having two types of bacterial consortia was to know whether the 28-day acclimatized river biofilms (Bacterial consortium B) had higher degradation ability than the 35-day acclimatized river biofilms (Bacterial consortium A).

Fifteen of the loofah sponges with the Bacterial consortium A were directly subjected to the degradation test. The remaining loofah sponges with Bacterial consortium A were put into three $500 \mathrm{ml}$ amber bottles and preserved at 25,4 and $-20^{\circ} \mathrm{C}$, respectively. The preserved temperatures of 25,4 and $-20{ }^{\circ} \mathrm{C}$ represented the temperatures of culturing, low metabolic activity and no metabolic activity for acclimatized bacterial consortia, respectively. This setting was to determine the effect of the preserved temperature on the degradation ability of bacterial consortia. Each bottle contained 30 loofah sponges and $400 \mathrm{ml}$ MSM with $50 \mathrm{mg} \mathrm{l}^{-1}$ methomyl. After preservation for 1 and 3 months, 15 loofah sponges were removed from each bottle for degradation tests. The same procedures were performed for loofah sponges with Bacterial consortium B.

Degradation tests for acclimatized bacterial consortia on loofah sponges

Fifteen loofah sponges with the Bacterial consortium A or the Bacterial consortium B, which either did not undergo preservation or were preserved at different temperatures for different times, were put into 1-1 flasks containing $500 \mathrm{ml}$ MSM with $50 \mathrm{mg} \mathrm{l}^{-1}$ methomyl as the experimental groups. The control was $500 \mathrm{ml}$ MSM with $50 \mathrm{mg} \mathrm{l}^{-1}$ methomyl. The experiment and the control were both incubated at $25{ }^{\circ} \mathrm{C}$ with shaking at $150 \mathrm{rpm}$ using an orbital shaker (Hipoint ${ }^{\circledR}$ OS-54, Kaohsiung, Taiwan). Twenty ml MSM samples (in two replicates) were removed from the flasks at Day 0, 1, 3, 5 and 7 to determine the concentration of methomyl.

Degradation tests for isolated bacterial species

The acclimatized river biofilms on ceramic discs were removed into phosphate buffer solution ( $\mathrm{pH}$ 7.4, Sigma, St. Louis, MO) using a scraper and mild sonication. A small amount $(0.2 \mathrm{ml})$ of cell suspension was streaked onto an agar petri plate that contained MSM with $50 \mathrm{mg} \mathrm{l}^{-1}$ methomyl, and the plate was incubated at $25{ }^{\circ} \mathrm{C}$ for about 7 days using a thermostat incubator (Hipoint ${ }^{\circledR} 740$, Kaohsiung, Taiwan). Once colonies were observed, they were carefully removed by a sterilized platinum hook and re-streaked to obtain colonies of a single bacterial strain. The isolated bacterial strains were identified after DNA extraction and PCR amplification by the methods described above, followed by DNA sequencing (Tri-I Biotech, Inc., Taipei, Taiwan) using an ABI 3730 automatic DNA analyzer (Applied Biosystems $\left.{ }^{\circledR}, C A\right)$. The nucleotide sequence was edited with Lasergene V.5.06 software (DNASTAR, Madison). To determine the phylogenetic affiliation, a similarity search was performed using BLAST (Basic Local Alignment Search Tool, http://blast.ncbi.nlm.nih.gov/Blast.cgi, USA) program for the comparison of the nucleotide query sequence against a nucleotide sequence database.

Each isolated bacterial strain was grown on 10 petri plates containing solidified MSM with $50 \mathrm{mg} \mathrm{l}^{-1}$ methomyl. When large numbers of colonies appeared, they were removed by a sterilized platinum hook into a 1-1 flask containing $500 \mathrm{ml}$ MSM with $50 \mathrm{mg} \mathrm{l}^{-1}$ methomyl and 15 artificial sponges (made by melamine, D\&O Biotechnology Co., Ltd., Kaohsiung, Taiwan), and then incubated for 5 days to allow bacteria to grow and attach onto the sponges. This type of artificial sponge has denser holes and more surface area for bacterial attachment than the loofah sponge. These differences might improve the methomyl degradation capacity of bacteria. Fifteen sponges with large amounts of a single bacterial strain attached were placed in a 1-1 flask containing $500 \mathrm{ml}$ MSM with $50 \mathrm{mg}^{-1}$ methomyl as the experimental group. The control group contained $500 \mathrm{ml}$ MSM with $50 \mathrm{mg} \mathrm{l}^{-1}$ methomyl and no sponges. To determine the effect of an additional carbon source on the degradation of methomyl by isolated bacterial strains, another set of experiments was run with glucose $(46.27 \mathrm{mg} / \mathrm{L}$, PRS Panreac, Barcelona, Spain) added.

\section{Analysis of concentrations of methomyl}

Twenty $\mathrm{mL}$ of MSM collected from different degradation tests were filtered with Nylon filter membranes $(25 \mathrm{~mm}$ diameter, $0.22 \mu \mathrm{m}$ pore size, Great Engineering Technology, Taipei, Taiwan). The filtrate was added to the same amount of acetonitrile (99.9\%, HPLC grade, Tedia, Touffen, Taiwan) and injected into a High Performance Liquid Chromatography device (HPLC, Agilent 1100, Agilent Technologies, Santa Clara, CA) to analyze the concentration of methomyl. The HPLC column was an Ascentis $\mathrm{C}_{18}(25 \mathrm{~cm}$ long $\times 4.6 \mathrm{~mm}$ diameter, $5 \mu \mathrm{m}$ particle size, Supelco, Pittsburgh, PA). The mobile phase was 50:50 acetonitrile and double deionized water with a flow rate of $1 \mathrm{ml} \mathrm{min}^{-1}$. A UV detector was used with the detection wavelength of $254 \mathrm{~nm}$. 
The spike samples were produced by spiking known amounts of pesticide in blank MSM and subsequently carrying out the same procedure as described above to check the recovery of methomyl during analysis. The recoveries of methomyl were calculated by dividing the concentrations of spiked samples (after subtraction of the concentration of an unspiked, blank sample) with the original spiked concentrations. The recoveries of methomyl in blank MSM ranged from 102.9 to $109.7 \%$. Procedural blanks and quality control check samples were included in every batch of samples. The precision of the 5 and $20 \mathrm{mg} \mathrm{l}^{-1}$ of methomyl standards was 3.5-6.7 and 2.5-5.9\%, respectively. The method detection limit for methomyl was $1.64 \mathrm{mg}^{-1}$.

\section{Results and discussion}

Removal of methomyl by acclimatized river biofilms on ceramic discs

After the 28-day enrichment culture, river biofilms on ceramic discs showed a high, significant ability to remove added methomyl from MSM (90.6 \% removal, MannWhitney $U$ test between experimental and control groups, $p<0.05$ ) within 7 days (Fig. 1). There was no decrease of methomyl in the control group that lacked river biofilms. Only small amounts (less than $1 \%$ ) of methomyl were found to adsorb onto river biofilms. These results indicated

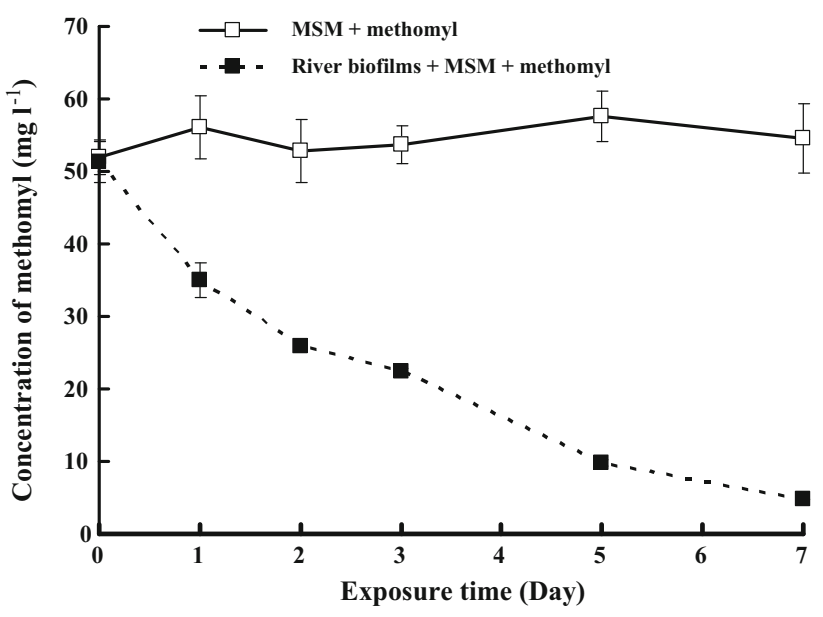

Fig. 1 Changes in mean concentration of methomyl in mineral salt medium (MSM) with and without acclimatized river biofilms on ceramic discs for 7 days at $25{ }^{\circ} \mathrm{C}$. (The error bar represents the standard deviation of two replicates) that most of the removed methomyl was degraded by microorganisms within the acclimatized river biofilms grown on ceramic discs. Similarly, Carvalho et al. (2002) found that a microbial consortium obtained from soil after 4 months of culturing in MSM enriched with fluorobenzene was able to grow on and degrade fluorobenzene that was supplied as the sole carbon source. In a different study, a mixture of activated sludge was able to aerobically biodegrade more than $70 \%$ of methomyl within 8 days (Farré et al. 2002).

Changes in bacterial diversity of river biofilms on ceramic discs

The banding pattern of the DGGE gel showed changes in the bacterial community structure of river biofilms during the enrichment culture and the degradation test. Cluster analysis was used to examine the different DGGE banding patterns in terms of the structural diversity. The dendrogram of similarity in bacterial communities between different treatments is shown in Fig. 2. It revealed two major groups, which corresponded to the effect of methomyl on bacterial communities. River biofilms on ceramic discs during the 28-day enrichment culture belonged to the same clustering group, which differentiated them from those after 28-day enrichment culture followed by the degradation test for 7 days. River biofilms exposed to methomyl for 28 days were most similar to those exposed for 21 days, followed by those exposed for 14 and 7 days, but they were less similar to those without methomyl exposure (Day 0). These results indicated that the longer a river biofilm was exposed to methomyl, the less similar its bacterial community structure was to the original bacterial community structure of the river biofilm. This may be because bacterial species sensitive to methomyl disappeared and only those tolerant to methomyl and capable of degrading methomyl survived (Tien et al. 2013).

Removal of methomyl by acclimatized bacterial consortia on loofah sponges

Bacterial consortium A was removed from the ceramic discs covered with river biofilms and acclimatized in methomyl for 28 days, and was then attached onto loofah sponges. Bacterial consortium B was removed from the ceramic discs covered with river biofilms and acclimatized in methomyl for 28 days, followed by the 7-day degradation test. During the degradation test (Fig. 3), no 
Fig. 2 Clustering analysis (using Dice's similarity coefficient) of the DGGE patterns of $16 \mathrm{~S}$ rDNA fragments amplified from river biofilms on ceramic discs during the continuous enrichment culture for $0,7,14,21$ and 28 days, and followed by the degradation test for 7 days

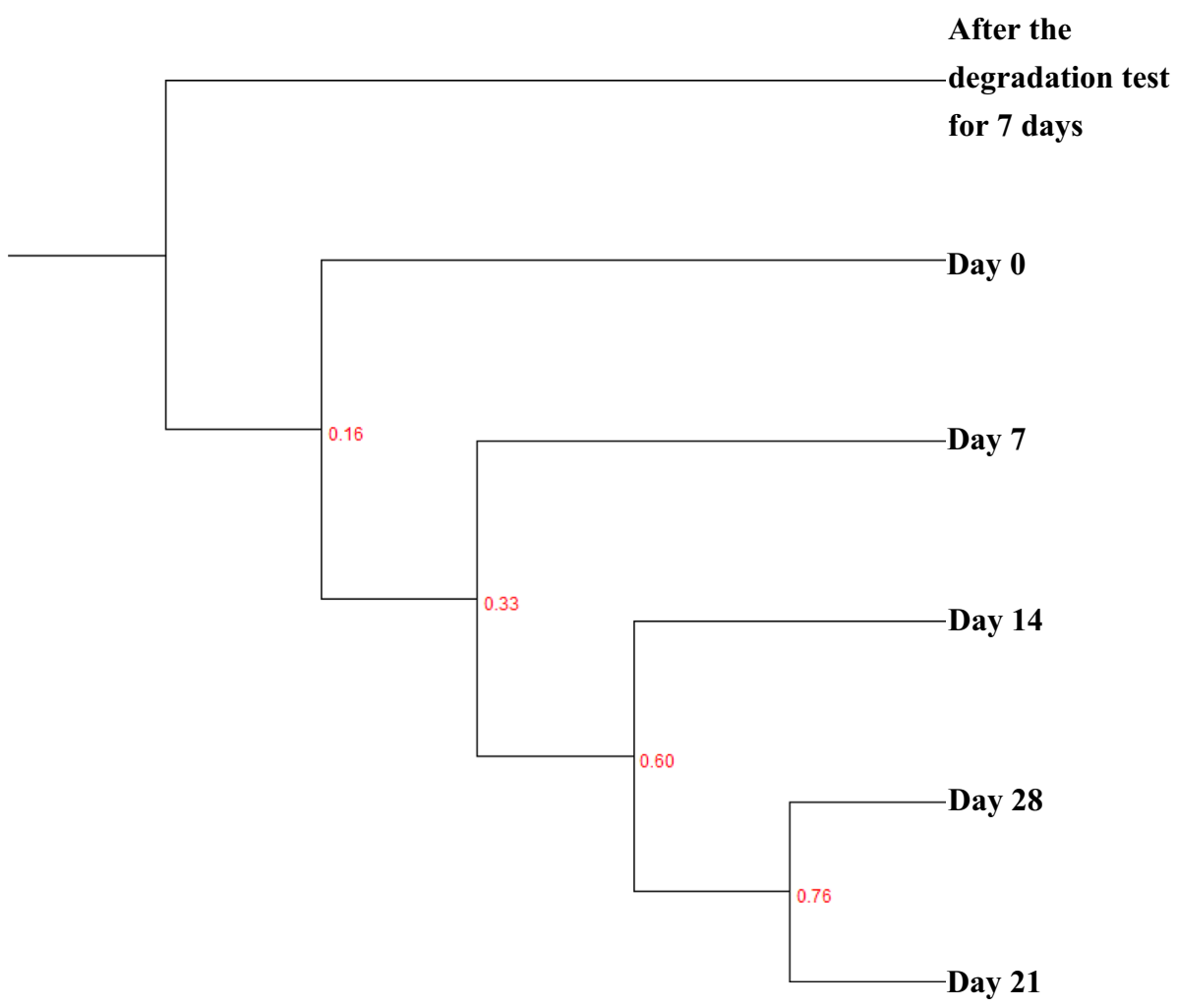

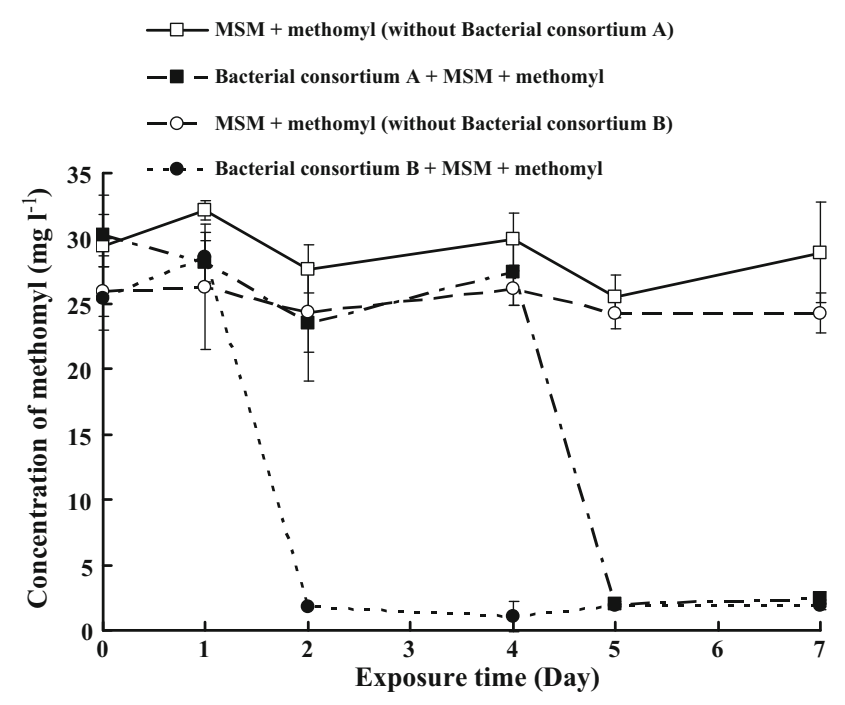

Fig. 3 Changes in mean concentration of methomyl in mineral salt medium (MSM) with and without Bacterial consortium A or B on loofah sponges for 7 days at $25^{\circ} \mathrm{C}$. (The error bar represents the standard deviation of two replicates) methomyl was removed by Bacterial consortium A in the first 4 days, but a sharp decrease $(92.2 \%)$ of methomyl was found at Day 5. In contrast, Bacterial consortium B showed a sharp decrease $(92.4 \%)$ of methomyl at Day 2. Although there was no significant difference (MannWhitney $U$ test, $p>0.05$ ) in the degradation capacity between Bacterial consortium A and Bacterial consortium $\mathrm{B}$ in the 7-day degradation test, Bacterial consortium B removed methomyl more quickly than Bacterial consortium A. This might be because Bacterial consortium B was exposed to methomyl for a longer time (35 days) and most likely contained more methomyl-degrading bacterial species than Bacterial consortium A. However, Norhani and Firdausi (2008) found that acclimatization of microorganisms to phenol had improved microbe's affinity to the substrate, but no significant improvement in phenol reduction shown by acclimatized culture compared to non-acclimatized one.

To investigate the usefulness of these bacterial consortia to remediate methomyl-contaminated water, the stability of 
their degradation ability during long-term preservation was also tested. After preservation for 1 month, the 7-day removal rates for Bacterial consortium A preserved at 25, 4 and $-20{ }^{\circ} \mathrm{C}$ were 4,9 and $3 \%$, respectively, and those for Bacterial consortium B preserved at 25,4 and $-20{ }^{\circ} \mathrm{C}$ were 6,11 and $25 \%$, respectively. After 3 months of preservation, the 7-day removal rates for Bacterial consortium A preserved at 25,4 and $-20{ }^{\circ} \mathrm{C}$ were $21.5,5$ and $16.9 \%$, respectively, and those for Bacterial consortium B at 25, 4 and $-20{ }^{\circ} \mathrm{C}$ were $2,2.4$ and $6.1 \%$, respectively. These results showed a significant decrease (Mann-Whitney $U$ test, $p<0.05)$ in the methomyl degradation ability of Bacterial consortium A and Bacterial consortium B after preservation at 25,4 and $-20^{\circ} \mathrm{C}$ for 1 and 3 months. These results suggested that the methomyl-degrading bacterial species might die or lose their ability to degrade methomyl during preservation (Lang and Malik 1996). It is also possible that the preserved bacterial consortia might need more time to recover their methomyl-degrading ability; thus, we did not observe high removal rates within 7 days. In contrast, Nagas et al. (2006) found that the degradation ability of an immobilized consortium for carbendazim and 2,4-dichlorophenoxyacetic acid could be stably maintained at least 6 months by simple preservation methods. Therefore, more studies are needed to obtain the best preservation technique for the methomyl-degrading consortia.

Removal of methomyl by isolated bacterial strains

Three bacterial species were isolated from the methomylacclimatized river biofilms: Sphingomonas sp., Pseudomonas sp. and Sphingobacterium sp. The Sphingomonas sp. belongs to the alphaproteobacteria group, and it is a Gram-negative, aerobic and rod-shaped bacteria. Sphingomonas species are widely distributed in nature and have a unique ability to degrade refractory contaminants (White et al. 1996). Some strains of Sphingomonas sp. have been found to be able to degrade 2-methylphenanthrene, hydroxydibenzofurans, methoxydibenzofurans, toluene, naphthalene, phenanthrene and benzoate (Harms et al. 1995; Fredrickson et al. 1995; Ni'matuzahroh et al. 1999; Huang et al. 2008). Some Sphingomonas species can utilize diphenyl ether and dibenzo-p-dioxin as sole sources for carbon and energy (Schmidt et al. 1992; Wittich et al. 1992). The Pseudomonas sp. is Gram-negative, rodshaped, aerobic gammaproteobacteria and has widespread occurrence in water and in plant seeds. Some members of Pseudomonas are able to degrade cyanide, carbaryl, pen-
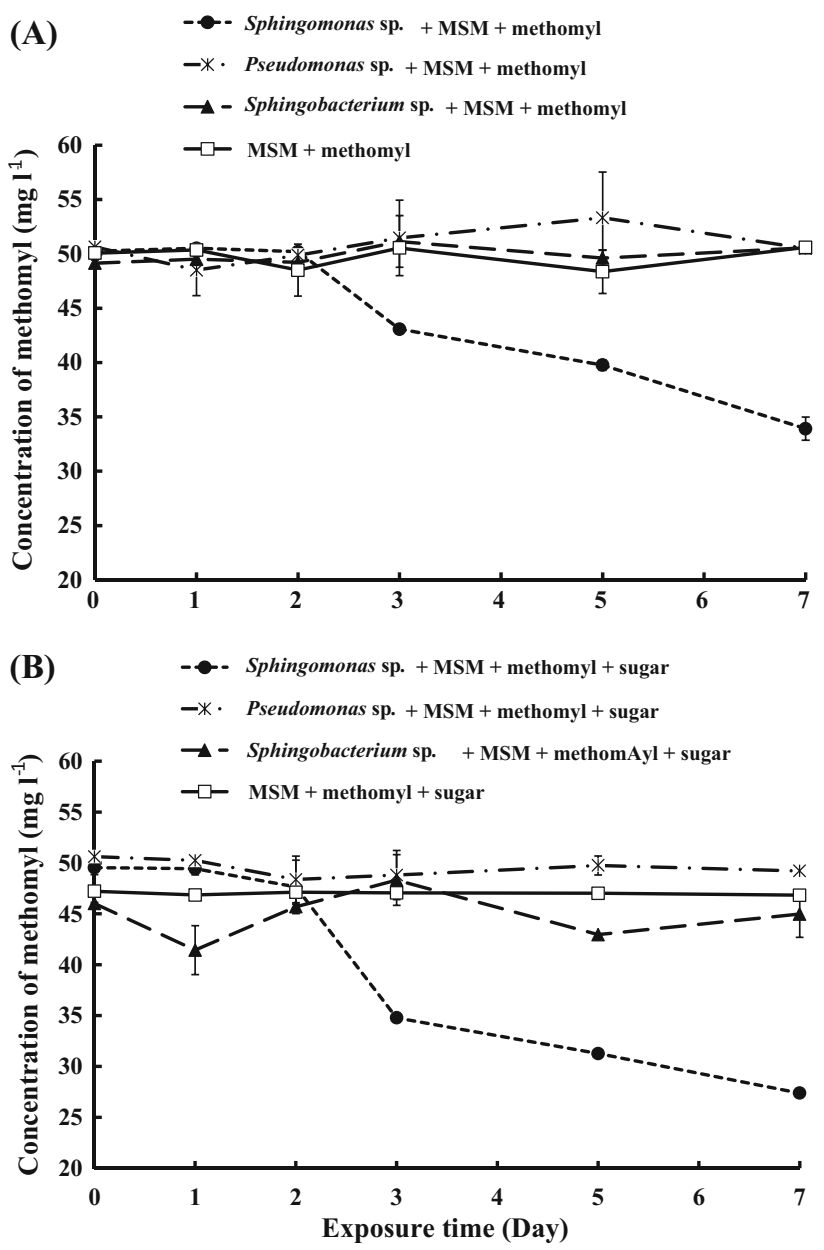

Fig. 4 Changes in concentration of methomyl in mineral salt medium (MSM) with and without isolated bacterial species for 7 days at $25^{\circ} \mathrm{C}$ under $\mathbf{a}$ the absence and $\mathbf{b}$ the presence of glucose. (The error bar represents the standard deviation of two replicates)

tachlorophenol, polycyclic aromatic hydrocarbon and crude oil (Nam et al. 2003; O'Mahony et al. 2006; Huertas et al. 2006; Dasgupta et al. 2013; Singh et al. 2013). The Sphingobacterium sp. is a Gram-negative, rod-shaped, aerobic species. Some strains of Sphingobacterium are able to degrade mefenacet when used as the sources of carbon and energy, and decolorize the dye Direct Blue GLL (Ye et al. 2004; Tamboli et al. 2010).

The ability of these three isolated bacterial strains to degrade methomyl, with or without the presence of glucose, is shown in Fig. 4. No methomyl was removed by two isolated bacterial species (Pseudomonas sp. and Sphingobacterium sp.) and in the control group. However, the Sphingomonas sp. was significantly able to remove 
methomyl with a 7-day removal rate of $44.7 \%$ when glucose was added (Fig. 4b), and $32.5 \%$ without glucose (Fig. 4a) (Mann-Whitney $U$ test, $p<0.05$ ). The result suggested that the presence of the additional carbon source (i.e. glucose) might improve the methomyl-degrading ability of Sphingomonas sp. or might increase the growth of this strain, resulting in more methomyl being removed from the medium. Sharmila et al. (1989) also found that fenitrothion was degraded by Bacillus sp. only in the presence of yeast extract. Several bacterial species isolated from the soil showed lower degradation activity regarding parathion, molinate and isoxathion in a medium enriched by nutrients (e.g. glucose) than in a nutrient-poor medium (Imai and Kuwatsuka 1986; Ohshiro et al. 1996). The less than $50 \%$ of methomyl-degrading rates for Sphingomonas sp. might be because the experimental conditions (e.g. pH $7,25^{\circ} \mathrm{C}$ ) were not suitable to the growth of this strain. Some environmental factors (e.g. pH, temperature and nutrients) have been found to affect the degradation activity of microorganisms (Pattanasupong et al. 2004a; Nagas et al. 2006). Therefore, further study of the optimum conditions for improving the degradation activity of isolated bacterial species is essential.

Many methomyl-degrading bacterial strains have been found, such as Vibrio fischeri, Paracoccus sp. mdw-1 and Stenotrophomonas maltophilia M1 (Farré et al. 2002; Xu et al. 2009; Mohamed 2009). Although the Pseudomonas sp. did not show a methomyl-degrading ability in the current study, El-Fakharany et al. (2011) found that Pseudomonas spp. (EB20) was able to degrade $77 \%$ of methomyl (10 $\mathrm{mg}^{-1}$ ) within 2 weeks, and Madhuri and Rangaswamy (2009) found that 26-58 \% of methomyl had been eliminated by Pseudomonas sp. in 7 days. It indicated that these Pseudomonas species should belong to different strains.

It has been suggested that a microbial consortium can show a higher degradation ability than a single strain because it contains both the degraders of target compounds and strains that could utilize the metabolic intermediates of the target compounds (Pattanasupong et al. 2004b). This agreed with our results where acclimatized bacterial mixtures (i.e. acclimatized river biofilms, Bacterial consortium A and Bacterial consortium B) showed higher methomyl removal rates (90.6-92.4\%) than isolated bacterial species (Sphingomonas sp., $32.5 \%$ ). Thus, acclimatized bacterial consortia have a higher potential to be used in remediation of methomyl-contaminated water than a single bacterial strain.

\section{Conclusion}

This study has demonstrated that the bacterial consortia acclimatized from river biofilms had higher methomyldegrading ability than single bacterial strains isolated from acclimatized river biofilms, but this ability was decreased after preservation at 25,4 and $-20{ }^{\circ} \mathrm{C}$ for 1 and 3 months. Thus, bacterial consortia were the good biomaterial for bioremediation of methomyl-contaminated water. The 35-day acclimatized bacterial consortia degraded methomyl faster than the 28-day acclimatized ones, but both bacterial consortia have similar degradation capacity. Although many studies observed that Sphingomonas sp. was able to degrade several organic pollutants, this study was the first to show its ability to degrade methomyl. The degradation ability of this species to methomyl was improved by adding glucose.

Acknowledgments This work was funded by National Science Council, Taiwan with the project no. NSC96-2313-B-017-001-MY3.

\section{References}

Araya R, Yamaguchi N, Tani K, Nasu M (2003) Changes in the bacterial community of natural river biofilm during biodegradation of aniline-derived compounds determined by denaturing gradient gel electrophoresis. J Heal Sci 49(5):379-385

Carvalho MF, Alves CCT, Ferreira MIM, De Marco P, Castro PM (2002) Isolation and initial characterization of a bacterial consortium able to mineralized fluorobenzene. Appl Environ Microbiol 68(1):102-105

Chang YJ, Stephen JR, Richter AP, Venosa AD, Brüggemann J, Macnaughton SJ, Kowalchuk GA, Haines JR, Kline E, White DC (2000) Phylogenetic analysis of aerobic freshwater and marine enrichment culture efficient in hydrocarbon degradation: effect of profiling method. J Microbiol Method 40(1):19-31

Crump BC, Bahr GW, Michele B, Hobbie JE (2003) Bacterioplankton community shifts in an arctic lake correlate with seasonal changes in organic matter source. Appl Environ Microbiol 69(4):2253-2268

Dasgupta D, Ghosh R, Sengupta TK (2013) Biofilm-mediated enhanced crude oil degradation by newly isolated Pseudomonas species. ISRN Biotechnol 2013:1-13

El-Fakharany II, Massoud AH, Derbalah AS, Saad Allah MS (2011) Toxicological effects of methomyl and remediation technologies of its residues in an aquatic system. J Environ Chem Ecotoxicol 3(13):332-339

Farré M, Fernandez J, Paez M, Granada L, Barba L, Gutierrez HM, Pulgarin C, Barceló D (2002) Analysis and toxicity of methomyl and ametryn after biodegradation. Anal Bioanal Chem 373(8):704-709

Ferris MJ, Muyzer G, Ward DM (1996) Denaturing gradient gel electrophoresis profiles of $16 \mathrm{~S}$ rRNA-defined populations inhab- 
iting a hot spring microbial mat community. Appl Environ Microbiol 62(2):340-346

Fredrickson JK, Balkwill DL, Drake GR, Romine MF, Ringelberg DB, White DC (1995) Aromatic-degrading Sphingomonas isolates from the deep subsurface. Appl Environ Microbiol 61(5):1917-1922

Harms H, Wilkes H, Wittich RM, Fortnagel P (1995) Metabolism of hydroxydibenzofurans, methoxydibenzofurans, acetoxydibenzofurans and nitrobenzofurans by Sphingomonas sp. strain HH69. Appl Environ Microbiol 61(7):2499-2505

Heuer H, Drsek M, Baker P, Smalla K, Wellington EMH (1997) Analysis of actinomycete communities by specific amplification of genes encoding 16S rRNA and gel-electrophoretic separation in denaturing gradients. Appl Environ Microbiol 63(8):3233-3241

Hitchcock AP, Dynes JJ, Lawrence JR, Obst M, Swerhone GDW, Korber DR, Leppard GG (2009) Soft X-ray spectromicroscopy of nickel sorption in a natural river biofilm. Geobiology 7(4):432-453

Huang X, Tian Y, Luo YR, Liu HJ, Zheng W, Zheng TL (2008) Modified sublimation to isolate phenanthrene-degrading bacteria of the genera Sphingomonas and Burkholderia from Xiamen oil port. Mar Poll Bull 57(6-12):538-543

Huertas MJ, Luque-Almagro VM, Martínez-Luque M, Blasco R, Moreno-Vivián C, Castillo F, Roldán MD (2006) Cyanide metabolism of Pseudomonas pseudoalcaligenes CECT5344: role of siderophores. Biochem Soc Trans 34(Pt 1):152-155

Imai Y, Kuwatsuka S (1986) The mode of metabolism of the herbicide molinate by four strains of microorganisms isolated from soil. J Pest Sci 11(2):111-117

Lang E, Malik KA (1996) Maintenance of biodegradation capacities of aerobic bacteria during long-term preservation. Biodegradation 7(1):65-71

Lawrence JR, Kopf G, Headley JV, Neu TR (2001) Sorption and metabolism of selected herbicides in river biofilm communities. Can J Microbiol 47(7):634-641

Lyautey E, Lacoste B, Ten-Hage L, Rols J-L, Garabetian F (2005) Analysis of bacterial diversity in river biofilms using 16S rDNA PCR-DGGE: methodological settings and fingerprints interpretation. Water Res 39(2-3):380-388

Madhuri RJ, Rangaswamy V (2009) Biodegradation of selected insecticides by Bacillus and Pseudomonas sps in ground nut fields. Toxicol Inter 16(2):127-132

Malato S, Blanco J, Cáceres J, Fernández-Alba AR, Agüera A, Rodríguez A (2002) Photocatalytic treatment of water-soluble pesticides by photo-Fenton and $\mathrm{TiO}_{2}$ using solar energy. Catal Today 76(2-4):209-220

Mohamed MS (2009) Degradation of methomyl by the novel bacterial strain Stenotrophomonas maltophilia M1. Electron J Biotechnol 12(4): $1-6$

Muyzer G, deWall EC, Uitterlinden AG (1993) Profiling of complex microbial populations by denaturing gradient gel electrophoresis analysis of polymerase chain reaction-amplified genes coding for 16S rRNA. Appl Environ Microbiol 59(3):695-700

Nagas H, Pattanasupong A, Sugimoto E, Tani K, Nasu M, Hirata K, Miyamoto K (2006) Effect of environmental factors on performance of immobilized consortium system for degradation of carbendazim and 2,4-dichlorophenoxyacetic acid in continuous culture. Biochem Eng J 29(1):163-168

Nam IH, Chang YS, Hong HB, Lee YE (2003) A novel catabolic activity of Pseudomonas veronii in biotransformation of pentachlorophenol. Appl Microbiol Biotechnol 62(2-3):284-290
Ni'matuzahroh, Gilewicz M, Guiliano M, Bertrand JC (1999) In-vitro study of interaction between photooxidation and biodegradation of 2-methylphenanthrene by Sphingomonas sp. 2MPII. Chemosphere 38(11):2501-2507

Norhani J, Firdausi R (2008) Microbial consortia from residential wastewater for bioremediation of phenol in a chemostat. J Teknol 48(F):51-60

Ohshiro K, Kakuta T, Sakai T, Hirota H, Hoshino T, Uchiyama T (1996) Biodegradation of organophosphorus insecticides by bacteria isolated from turf green soil. J Ferm Bioeng 82(3):299-305

O’Mahony MM, Dobson AD, Barnes JD, Singleton I (2006) The use of ozone in the remediation of polycyclic aromatic hydrocarbon contaminated soil. Chemosphere 63(2):307-314

Pattanasupong A, Nagase H, Inoue M, Hirata K, Tani K, Nasu M, Miyamoto K (2004a) Ability of a microbial consortium to remove pesticide, carbendazim and 2,4-dichlorophenoxyacteic acid. World J Microbiol Biotechnol 20(5):517-522

Pattanasupong A, Nagase H, Sugimoto E, Hori Y, Hirata K, Tani K, Nasu M, Miyamoto K (2004b) Degradation of carbendazim and 2,4-dichlorophenoxyacetic acid by immobilized consortium on loofa sponge. J Biosci Bioeng 98(1):28-33

Rowan A, Snape J, Fearnside D, Barer M, Curtis T, Head I (2003) Composition and diversity of ammonia-oxidizing bacterial communities in wastewater treatment Reactors of different design treating identical wastewater. FEMS Microbiol Ecol 43(2): 195-206

Schmidt S, Witttich RM, Erdmann D, Wilkes H, Francke W, Fortnagel P (1992) Biodegradation of diphenyl ether and its monohalogenated derivatives by Sphingomonas sp. strain SS3. App. Environ Microbiol 58(9):2744-2750

Sharmila M, Ramanand K, Sethunathan N (1989) Effect of yeast extract on the degradation of organophosphorus insecticides by soil enrichment and bacterial cultures. Can J Microbiol 35(12):1105-1110

Singh R, Trivedi VD, Phale PS (2013) Metabolic regulation and chromosomal localization of carbaryl degradation pathway in Pseudomonas sp. strains C4, C5 and C6. Arch Microbiol 195(8):521-535

Tamboli DP, Kurade MB, Waghmodeb TR, Joshi SM, Govindwar SP (2010) Exploring the ability of Sphingobacterium sp. ATM to degrade textile dye Direct Blue GLL, mixture of dyes and textile effluent and production of polyhydroxyhexadecanoic acid using waste biomass generated after dye degradation. J Hazard Mater 182(1-3):169-176

Tien C-J, Chuang T-L, Chen CS (2011) The role of naturally occurring river biofilms on the degradation kinetics of diazinon. Clean: Soil, Air, Water 39(10):931-938

Tien C-J, Lin M-C, Chiu W-H, Chen CS (2013) Biodegradation of carbamate pesticides by natural river biofilms in different seasons and their effects on biofilms community structure. Environ Poll 179:95-104

USEPA (1998) Reregistration eligibility decision (RED)- Methomyl List A, Case 0028. EPA 738-R-98-021. Office of Prevention, Pesticides and Toxic Substances (7508C), United States Environmental Protection Agency, Washington, DC, 20460

Van Scoy AR, Yue M, Deng X, Tjeerdema RS (2013) Environmental fate and toxicology of methomyl. Rev Environ Contam Toxicol 222:93-109

Weisburg WG, Barns SM, Pelletier DA, Lane DJ (1991) 16S ribosomal DNA amplification for phylogenetic study. J Bacteriol 173(2):697-703 
White DC, Sutton SD, Ringelberg DB (1996) The genus Sphingomonas: physiology and ecology. Curr Opin Biotechnol 7(3):301-306

Wittich RM, Wilkes H, Sinnwell V, Francke W, Fortnagel P (1992) Metabolism of dibenzo-p-dioxin by Sphingomonas sp. strain RW1. Appl Environ Microbiol 58(3):1005-1010
Xu J-L, Wu J, Wang Z-C, Wang K, Li M-Y, Jiang J-D, He J, Li S-P (2009) Isolation and characterization of a methomyl-degrading Paracocus sp. mdw-1. Pedosphere 19(2):238-243

Ye YF, Min H, Du YF (2004) Characterization of a strain of Sphingobacterium sp. and its degradation to herbicide mefenacet. J Environ Sci (China) 16(2):343-347 